\title{
KUALITAS SUMBER DAYA MANUSIA DITINJAU DARI TINGKAT PENDIDIKAN, PELATIHAN KERJA DAN PENGALAMAN KERJA DI BALAI LATIHAN KERJA (BLK) TECHNOPARK GANESHA SUKOWATI SRAGEN
}

\author{
Mei Anjarwati, Bambang Mursito, Sarsono \\ Fakultas Ekonomi Jurusan Managemen, Universitas Islam Batik Surakarta \\ E-mail:anjarmei45@gmail.com
}

\begin{abstract}
This aims to find out the effect based on the simultaneously and partially method in the observation of education level, job training, and work experience in Balai Latihan Kerja (BLK) Technopark Ganesha Sukowati Sragen. Furthermore, this research also aims to know, are the training participants, after doing the training in Balai Latihan Kerja (BLK) Technopark Ganesha Sukowati Sragen able to get a job. The design of this research is descriptive quantitative. The entire population is used as the sample, there are 53 respondents, by using the saturation sampling technique. Retrieval of the data is using questionnaires. The analysis technique that used is multiple linear regressions. The result of this research explains that the $F$-test in educational level, job training, and work experiences simultaneously and significantly affect the quality of human resources of participants in Balai Latihan Kerja (BLK) Technopark Ganesha Sukowati Sragen. The T- test result explains that the level of education, job training, and work experiences partially have a positive and significant effect on the quality of human resources of participants in Balai Latihan Kerja (BLK) Technopark Ganesha Sukowati Sragen. The multiple linear regressions model in this research is $Y=10,278+0,117 \times 1+0,216$ $X 2+0,299 X 3+e$. To improve the abilities and skills of each individual, they have to attend training and have work experiences, even though they have a low level of education, it does not rule out the possibility of superior quality human resources can be achieved by them. Thus, the individual is able to compete in the working world.
\end{abstract}

Keywords: The quality of human resources, education level, job training, work experience

\section{PENDAHULUAN}

Menurut Badan Pusat Statistik pada Februari 2019, angka tingkat pengangguran terbuka di Indonesia turun menjadi 5,01 persen. Dalam setahun terakhir, pengangguran berkurang lima puluh ribu orang. Lulusan Sekolah Menengah Kejuruan (SMK) mendominasi jumlah pengangguran tersebut daripada tingkat pendidikan yang lain. Kurangnya kemampuan sumber daya manusia yang dibutuhkan industri menjadi penyebab utama pengangguran. Faktor utama dalam perusahaan ataupun organisasi adalah sumber daya manusia. Apapun bentuk organisasi, sumber daya manusia yang berkualitas sangat diperlukan supaya sasaran dapat terlaksana secara efektif dan efisien.

Pendidikan merupakan pokok dalam mencapai kesejahteraan dan keutuhan hidup manusia. Tingkat pendidikan yang tinggi diharapkan mampu menciptakan kualitas sumber daya manusia yang baik. Sehingga diharapkan ikut berkontribusi untuk diri sendiri maupun untuk organisasi. Optimasi melalui pelatihan dan pendidikan juga berpengaruh terhadap peningkatan kualitas sumber daya manusia (Hapsari et. al. 2019)

Pelatihan kerja dan pengembangan diri dibutuhkan para tenaga kerja untuk menambah kemampuan dan keahlian dalam bekerja. Pelatihan kerja yang dilakukan dengan materi serta metode yang tepat akan memungkinkan menaikan kualitas sumber daya manusia. Pelatihan kerja 
bukan hanya menguntungkan organisasi atau perusasahaan, namun juga dapat dijadikan pedoman oleh tenaga kerja itu sendiri.

Faktor yang juga mempengaruhi kemampuan kerja dan kualitas sumber daya manusia adalah seberapa berpengalaman seseorang. Pengalaman kerja yang dimiliki seseorang mempengaruhi peningkatan penguasaaan keterampilan (softskill). Maka semakin banyak pengalaman kerja, semakin tinggi pula penguasaaan keterampilan (Pamungkas, Hamid, dan Prasetya, 2017).

Pemberian pelatihan kerja di Balai Latihan Kerja (BLK) Tecnopark Ganesha Sukowati Sragen bukan hanya bertujuan untuk memenuhi kebutuhan perusahaan. Akan tetapi juga bertujuan untuk mendorong para peserta menjadi wirausahawan. Seperti pelatihan menjahit, konstruksi bangunan, teknisi otomotif, pengolahan hasil pertanian dan lain-lain. Pelatihan tersebut bisa menjadi bekal para peserta untuk membuka usaha dan mampu membuka industri rumahan sendiri. Dengan demikian dapat menurunkan angka pengangguran di Indonesia.

Berlandaskan latar belakang tersebut, maka peneliti mengangkat judul "Kualitas Sumber Daya Manusia Ditinjau dari Tingkat Pendidikan, Pelatihan Kerja, dan Pengalaman Kerja di Balai Latihan Kerja (BLK) Technopark Ganesha Sukowati Sragen."

\section{LANDASAN TEORI}

a. Kualitas Sumber Daya Manusia

Sumber daya manusia merupakan aset non materil di dalam suatu organisasi bisnis yang dapat mewujudkan eksistensi organisasi (Sukarjati, Minarsih, dan Warso, 2016: 4). Sedangkan menurut Amhas (2018: 138) kualitas sumber daya manusia adalah sumber daya yang mempunyai kompetensi unggul dari aspek fisik ataupun aspek intelektual.

b. Tingkat Pendidikan

Menurut pendapat Pamungkas, Hamid, dan Prasetya (2017: 2) pendidikan merupakan salah satu dari banyak faktor yang memiliki pengaruh atas kemampuan dan kinerja karyawan. Tingkat pendidikan adalah tahapan seseorang dalam memperoleh ilmu pengetahuan yang menggunakan teknik dan metode belajar mengajar di instansi pendidikan/sekolahan dalam jangka waktu tertentu (Mandang, Lumanauw, Walangitan, 2017:4325).

c. Pelatihan Kerja

Pelatihan adalah proses pendidikan sekilas yang mengguanakan mekanisme sistematis dan terorganisir sehingga daya non manajerial menggali pengetahuan dan keterampilan teknis untuk misi tertentu (Iskandar, 2018: 25). Pelatihan kerja merupakan serangkaian prosedur yang dilakukan dengan terencana dalam bentuk dorongan kepada seseorang atau tenaga kerja yang dilakukan oleh tenaga ahli/profesional dalam durasi tertentu yang bermaksud untuk menambah kemampuan dalam bidang tertentu.

d. Pengalaman Kerja

Pengalaman kerja adalah pengalaman seseorang dalam bidang pekerjaan tertentu. Seseorang dinyatakan berpengalaman dalam pekerjaan apabila telah melakukan suatu pekerjaan dalam kurun waktu tertentu (Riyadi, 2015: 49).

\section{METODLOGI PENELITIAN}

Jenis penelitian ini adalah penelitian kuantitatif deskriptif. Tempat penelitian di Badan Latihan Kerja (BLK) Technopark Ganesha Sukowati Sragen. Waktu penelitian dilaksanakan mulai Agustus 2019 - Januari 2020. Populasi penelitian ini adalah peserta pelatihan dan semua 
dijadikan sampel sejumlah 53 responden. Teknik sampling yang digunakan adalah teknik sampling jenuh, dimana sampel diambil dari seluruh populasi. Analisis regresi linier berganda merupakan alat uji pada penelitian ini.

\section{Uji Instrumen}

1) Uji Validitas

Tabel 1. Uji Validitas

\begin{tabular}{|c|c|c|}
\hline Butir Pernyataan & $\begin{array}{c}\text { Total Pearson } \\
\text { Correlatoin }\end{array}$ & Keterangan \\
\hline Kualitas Sumber Daya & & \\
Manusia & 0,298 & Valid \\
Pernyataan 1 & 0,361 & Valid \\
Pernyataan 2 & 0,572 & Valid \\
Pernyatan 3 & 0,486 & Valid \\
Pernyataan 4 & 0,649 & Valid \\
Pernyataan 5 & Valid \\
\hline Pernyataan 6 & 0,462 & Valid \\
\hline Tingkat Pendidikan & 0,788 & Valid \\
Pernyataan 1 & 0,788 & Valid \\
Pernyatan 2 & 0,842 & Valid \\
Pernyataan 3 & 0,894 & \\
Pernyataan 4 & & Valid \\
\hline Pelatihan Kerja & 0,613 & Valid \\
Pernyataan 1 & 0,546 & Valid \\
Pernyataan 2 & 0,632 & Valid \\
Pernyatan 3 & 0,676 & Valid \\
Pernyatan 4 & 0,513 & Valid \\
Pernyataan 5 & 0,721 & Valid \\
Pernyataan 6 & & Valid \\
\hline Pengalaman Kerja & 0,687 & Valid \\
Pernyataan 1 & 0,730 & Valid \\
Pernyatan 2 & 0,298 & Valid \\
Pernyataan 3 & 0,711 & Valid \\
Pernyataan 4 & 0,709 & \\
Pernyataan 5 & 0,799 & \\
Pernyataan 6 & &
\end{tabular}

Dari 22 item pertanyaan yang diajukan kepada 53 responden dinyatakan valid karena rhitung pada setiap pertanyaan lebih dari rtabel (rhitung $>0,228$ ).

2) Uji Reliabilitas

Tabel 2. Uji Reliabilitas

\begin{tabular}{|l|l|c|l|}
\hline \multicolumn{1}{|c|}{ Variabel } & \multicolumn{1}{c|}{$\begin{array}{c}\text { Cronbach's } \\
\text { Alpha }\end{array}$} & Kriteria & Keterangan \\
\hline $\begin{array}{l}\text { Kualitas Sumber } \\
\text { Daya Manusia } \\
\text { Tingkat Pendidikan }\end{array}$ & 0,651 & & Reliabel \\
$\begin{array}{l}\text { Pelatihan Kerja } \\
\text { Pengalaman Kerja }\end{array}$ & 0,822 & $\begin{array}{c}\text { Cronbach's } \\
\text { Alpha }>0,600\end{array}$ & $\begin{array}{l}\text { Reliabel } \\
\text { Reliabel } \\
\text { Reliabel }\end{array}$ \\
\hline
\end{tabular}

Berdasarkan tabel 2, dapat diartikan bahwa kualitas sumber daya manusia, tingkat pendidikan, pelatihan kerja, dan pengalaman kerja memiliki nilai koefisien reliabilitas $>$ dari Cronbach's Alpha yaitu 0,600.

3) Definisi Responden

a. Jenis Kelamin

Tabel 3. Klasifikasi Responden Berdasarkan Jenis Kelamin

\begin{tabular}{llll}
\hline No. & Jenis Kelamin & Jumlah (orang) & Persentase \\
\hline 1. & Laki-laki & 24 & $45,3 \%$ \\
2. & Perempuan & 29 & $54,7 \%$ \\
\hline & & & $100 \%$ \\
\hline
\end{tabular}


Jenis kelamin responden penelitian yang dominan adalah perempuan sebanyak 29 orang atau $54,7 \%$ dan sisanya pria sejumlah $45,3 \%$.

b. Umur

Tabel 4. Klasifikasi Responden Berdasarkan Umur

\begin{tabular}{cccc}
\hline No. & Umur & Jumlah (orang) & Persentase \\
\hline 1. & $18-25$ tahun & 44 & $83 \%$ \\
2. & $26-33$ tahun & 7 & $13,2 \%$ \\
3. & $34-41$ tahun & 2 & $3,8 \%$ \\
4. & $<42$ tahun & 0 & $0 \%$ \\
\hline \multicolumn{2}{r}{ Jumlah } & 53 & 100 \\
\hline
\end{tabular}

Umur responden penelitian yang paling banyak adalah berumur 18-25 tahun sebanyak 44 orang atau $83 \%$.

c. Tingkat pendidikan

Tabel 5. Klasifikasi Responden Berdasarkan Tingkat Pendidikan

\begin{tabular}{|c|c|c|c|}
\hline No. & Tingkat Pendidikan & Jumlah (orang) & Persentase (\%) \\
\hline 1. & SD & 0 & $0 \%$ \\
\hline 2. & SMP & 3 & $5,7 \%$ \\
\hline 3. & SMA/SMK & 38 & $71,7 \%$ \\
\hline 4. & D3 & 4 & $7,5 \%$ \\
\hline 5. & S1 & 8 & $15,1 \%$ \\
\hline & Jumlah & 53 & $100 \%$ \\
\hline
\end{tabular}

Tingkat pendidikan sebagian besar peserta pelatihan di BLK Technopark Ganesha Sukowati Sragen adalah lulusan SMA/SMK sebanyak 38 orang atau 71,7 \%.

\section{HASIL DAN PEMBAHASAN}

a. Uji Koefisien Determinasi (R2)

Dari nilai analisis data diperoleh Adjusted $R$ Square $\left(\mathrm{R}^{2}\right)=0,516$ maka variabel tingkat pendidikan, pelatihan kerja, dan pengalaman kerja mampu menjelaskan variasi variabel kualitas sumber daya manusia sebesar 51,6\%.

b. Analisis Regresi Linier Berganda

Persamaan regresinya sebagai berikut:

$$
\mathrm{Y}=10,278+0,177 \cdot \mathrm{X} 1+0,216 \cdot \mathrm{X} 2+0,299 \cdot \mathrm{X} 3
$$

Interprestasi dari persamaan regresi tersebut adalah:

- $\alpha=10,278$ artinya apabila tingkat pendidikan (X1), Pelatihan kerja (X2), dan pengalaman kerja (X3) sama dengan 0 (nol) atau konstan, maka kualitas sumber 
daya manusia akan bernilai 10,278.

- $\beta 1=0,177$ artinya apabila variabel tingkat pendidikan (X1) naik satu satuan akan menyebabkan kualitas sumber daya manusia meningkat sebesar 0,177. Asumsi pelatihan kerja (X2) dan pengalaman kerja (X3) tetap.

- $\quad \beta 2=0,216$ artinya apabila variabel pelatihan kerja (X2) naik satu satuan akan menyebabkan kualitas sumber daya manusia meningkat sebesar 0,216. Asumsi tingkat pendidikan (X1) dan pengalaman kerja (X3) tetap.

- $\quad \beta 3=0,299$ artinya apabila variabel pengalaman kerja (X3) naik satu satuan akan menyebabkan kualitas sumber daya manusia meningkat sebesar 0,299. Asumsi tingkat pendidikan (X1) dan pengalaman kerja (X3) tetap.

c. Uji Asumsi Klasik

1) Uji Normalitas

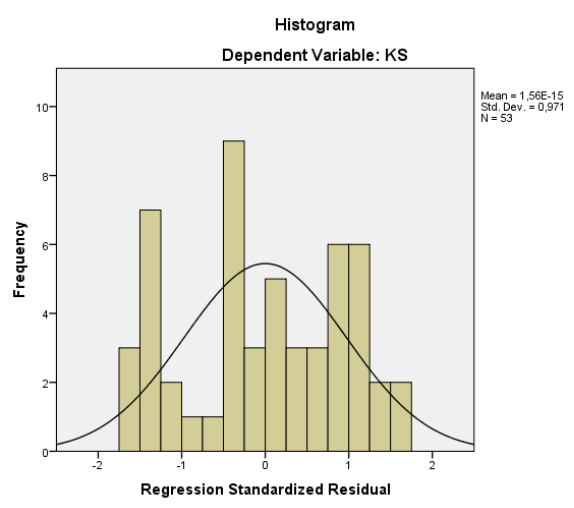

Gambar 1. Uji Normalitas

Bila dilihat dari gambar 1, pola histogram mengikuti kurva normal, walaupun ada beberapa data yang terlihat inlier dan outlier, namun secara garis besar distribusi data yang ada atas mengikuti kurva normal. Maka bisa disimpulkan bahwa data terdistribusi normal.

2) Uji Multikolinieritas

Tabel 6. Uji Multikolinieritas

\begin{tabular}{|c|c|c|c|}
\hline Variabel & Tolerance & VIF & Keterangan \\
\hline Tingkat & 0,914 & 1,094 & Tidak Terjadi \\
\hline Pendidikan & & & Multikolinearitas \\
\hline Pelatihan & 0,707 & 1,415 & Tidak Terjadi \\
\hline Kerja & & & Multikolinearitas \\
\hline Pengalaman & 0,741 & 1,349 & Tidak Terjadi \\
\hline Kerja & & & Multikolinearitas \\
\hline
\end{tabular}

Berdasarkan tabel di atas dapat dilihat bahwa Tingkat Pendidikan, Pelatihan Kerja, dan Pengalam Kerja masing- masing punya nilai tolerance $>0,10$ dan nilai VIF < 10. Maka dapat disimpulkan bahwa tidak timbul gangguan multikolinieritas dan dapat diinterprestasikan regresi ini terlepas dari multikolinieritas. 
3) Uji Heteroskedastisitas

Gambar 2. Uji Heteroskedasitas

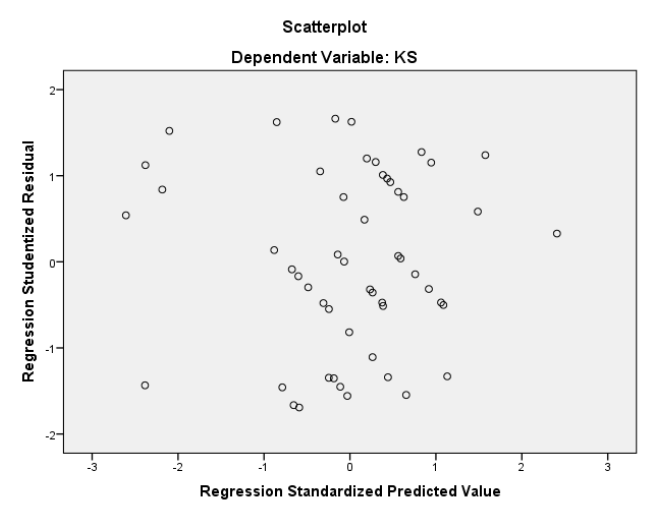

Gambar scatterplot di atas dapat dilihat bahwa titik-titik menyebar secara acak di bawah dan di atas angka 0 (nol) dan tidak menyusun pola tertentu. Dapat disimpulkan bahwa pada model regresi tidak timbul gejala heteroskedastisitas.

d. Uji Hipotesis

1) Uji Similtan (F)

Hasil dari uji simultan dengan program SPSS 21 didapat besarnya nilai Fhitung > Ftabel $(19,469>2,79)$ dengan signifikansi $0,000<0,05$. Maka bisa disimpulkan bahwa Ho ditolak, artinya variabel Tingkat Pendidikan, Pelatihan Kerja, dan Pengalaman Kerja berpengaruh simultan dan signifikan terhadap variabel Kualitas Sumber Daya Manusia peserta pelatihan BLK Technopark Ganesha Sukowati Sragen.

2) Uji Parsial (t)

- Variabel Tingkat Pendidikan mempunyai nilai thitung $(2,870)>2,00953$ dengan signifikansi 0,006 <0,05. Artinya Ho ditolak, secara parsial Tingkat Pendidikan memiliki pengaruh positif dan signifikan terhadap Kualitas Sumber Daya Manusia peserta pelatihan BLK Technopark Ganesha Sukowati Sragen.

- Variabel Tingkat Pendidikan mempunyai nilai thitung (2,203)> 2,00953 dengan signifikansi $0,032<0,05$. Artinya Ho ditolak, secara parsial Pelatihan Kerja memiliki pengaruh positif dan signifikan terhadap Kualitas Sumber Daya Manusia peserta pelatihan BLK Technopark Ganesha Sukowati Sragen.

- Variabel Tingkat Pendidikan mempunyai nilai thitung $(3,911)>2,00953$ dengan signifikansi $0,000<0,05$. Artinya Ho ditolak, secara parsial Pengalaman Kerja memiliki pengaruh positif dan signifikan terhadap Kualitas Sumber Daya Manusia peserta pelatihan BLK Technopark Ganesha Sukowati Sragen.

\section{Pembahasan}

a. Tingkat Pendidikan, Pelatihan Kerja, dan Pengalaman Kerja terhadap Kualitas Sumber Daya Manusia peserta pelatihan di BLK Technopark Ganesha Sukowati Sragen. 
Berdasarkan hasil uji hipotesis yang didapatkan dengan uji $\mathrm{F}$, diketahui bahwa Fhitung $(19,469)>$ Ftabel $(2,79)$ dan nilai signifikan sebesar $(0,000<0,05)$ sehingga Ho ditolak. Maka Tingkat Pendidikan, Pelatihan Kerja dan Pengalaman Kerja secara simultan dan signifikan berpengaruh terhadap Kualitas Sumber Daya Manusia peserta pelatihan BLK Technopark Ganesha Sukowati Sragen. Semakin tinggi Tingkat Pendidikan seseorang akan membuat mereka mempunyai kualitas sumber daya manusia yang baik pula. Para calon tenaga kerja yang mengikuti Pelatihan Kerja akan memiliki kemampuan dan keterampilan yang lebih dari sebelumnya. Dengan demikian kualitas sumber daya manusia yang mereka miliki juga lebih unggul. Semakin berpengalaman dalam bekerja, semakin baik pula sesorang dalam melaksanakan suatu pekerjaan tertentu. Dengan demikian semakin baik pula kuatitas sumber daya yang mereka punya.

b. Tingkat Pendidikan terhadap Kualitas Sumber Daya Manusia peserta pelatihan di BLK Technopark Ganesha Sukowati Sragen.

Berdasarkan hasil uji hipotesis yang didapatkan dengan uji t, diperoleh nilai thitung $(2,870)>$ tabel $(2,00953)$ dan nilai signifikansi $(0,006<0,05)$, jadi Ho ditolak. Maka Tingkat Pendidikan berpengaruh positif dan signifikan terhadap Kualitas Sumber Daya Manusia peserta pelatihan BLK Technopark Ganesha Sukowati Sragen. Peserta pelatihan yang mengikuti pelatihan di BLK Technopark Ganesha Sukowati Sragen terdidiri dari berbagai lulusan. Mulai dari Sekolah Dasar sampai Sarjana. Namun lulusan SMA sederajat yang mendominasi, karena fresh graduate membutuhkan pelatihan kerja untuk menambah kemampuan dan keahlian agar bisa bersaing di dunia kerja.

c. Pelatihan Kerja terhadap Kualitas Sumber Daya Manusia peserta pelatihan di BLK Technopark Ganesha Sukowati Sragen.

Berdasarkan hasil uji hipotesis yang didapatkan dengan uji t, diperoleh nilai thitung $(2,203)>$ tabel $(2,00953)$ dan nilai signifikansi $(0,032<0,05)$, jadi Ho ditolak. Maka Pelatihan Kerja berpengaruh positif dan signifikan terhadap Kualitas Sumber Daya Manusia peserta pelatihan BLK Technopark Ganesha Sukowati Sragen. Peserta yang mengikuti pelatihan tentunya mempunyai tujuan untuk meningkatan kualitas sumber daya manusia yang mereka punya. Dengan meningkatkan kemampuan dan keahlian, tentunya bisa menambah nilai tawar yang lebih baik di dunia kerja.

d. Pengalaman Kerja terhadap Kualitas Sumber Daya Manusia peserta pelatihan di BLK Technopark Ganesha Sukowati Sragen.

Berdasarkan hasil uji hipotesis yang didapatkan dengan uji t, diperoleh nilai thitung $(3,911)>$ tabel $(2,00953)$ dan nilai signifikansi $(0,000<0,05)$, jadi Ho ditolak. Maka Pengalaman Kerja berpengaruh positif dan signifikan terhadap Kualitas Sumber Daya Manusia peserta pelatihan BLK Technopark Ganesha Sukowati Sragen. Peserta pelatihan BLK Technopark Ganesha Sukowati Sragen bukan hanya fresh graduate saja, namun juga ada yang pernah bekerja. Menurut mereka pengalaman kerja mempengaruhi kemampuan saat bekerja. Penalaman kerja menjadi tolak ukur kualitas sumber daya manusia. Semakin lama sesorang bekerja dalam suatu bidang pekerjaan, semakin profesional pula dalam melakukan pekerjaan tersebut.

e. Tujuan diadakan pelatihan kerja untuk mengurangi angka pengangguran.

Sesuai visi instansi yaitu, menjadi lembaga inkubator industri berbasis teknologi yang dapat melahirkan wirausaha tangguh dan berdaya saing berdasarkan keunggulan ekonomi 
lokal. Berdasarkan data peserta pelatihan 2018, dari 320 peserta pelatihan sebagian besar mereka sudah mendapatkan pekerjaan di perusahaan dan membuka usaha mandiri. Dengan bekal kemampuan dan keahlian yang mereka punya, menjadikan mereka mudah mendapatkan pekerjan maupun membuka usaha mandiri. Dengan demikian angka pengangguran di Kabupaten Sragen dapat ditekan.

\section{KESIMPULAN}

Variabel Tingkat Pendidikan, Pelatihan Kerja, dan Pengalaman Kerja secara silmutan berpengaruh positif dan signifikan terhadap Kualitas Sumber Daya Manusia.Variabel Tingkat Pendidikan, Pelatihan Kerja, dan Pengalaman Kerja secara parsial berpengaruh positif dan signifikan terhadap Kualitas Sumber Daya Manusia. Dari data yang dimiliki Badan Latihan Kerja (BLK) Technopark Ganesha Sukowati Sragen pada 2018, peserta yang mengikuti pelatihan kerja disana sebagian sudah bekerja di suatu prusahaan atau instansi dan sebagian lainnya membuka usaha mandiri di rumah. Dengan demikian angka pengangguran di Kabupaten Sragen bisa lebih ditekan.

Untuk meningkatkan kemampuan dan keterampilan setiap individu hendaknya mengikuti pelatihan dan mempunyai pengalaman kerja, walaupun memiliki tingkat pendidikan rendah tidak menutup kemungkinan kualitas sumber daya manusia yang unggul bisa dicapai. Dengan demikian individu tersebut mampu bersaing di dunia kerja. Pelaksanaan pelatihan dirasa kurang lama, kurang untuk mempelajari semua materi dengan baik. Hasil penelitian ini diharapkan mampu memberi masukan kepada Instansi terkait yaitu Balai Latihan Kerja (BLK) Technopark Ganesha Sukowati Sragen dalam upaya meningkatkan kualitas sumber daya manusai peserta pelatihan.

\section{DAFTAR PUSTAKA}

Amhas, M. (2018). Pengaruh Kualitas Sumebr Daya Manusia, Kualitas Pelayanan dan Kinerja Pegawai terhadap Kepuasan Pelanggan pada Kantor Sistem Administrasi Manunggal Satu Atap (SAMSAT) Makasar 01 Selatan. Jurnal Mirai Management, vol. 2, No. 1, pp.136-149.

bps.go.id, (2019, 05 Mei), Februari 2019: Tingkat Pengangguran Terbuka (TPT) sebesar 5,01 persen, diakses pada 01 Oktober 2019, dari https://www.bps.go.id/pressrele ase/2019/05/06/1564/februari-2019--tingkat-pengangguran- terbuka--tpt--sebesar-5-01persen.html

Hapsari, A., Nurlaela, S., \& Titisari, K. H. (2019). Human Resources Optimization And Utilization Of Accrual Based Accounting Information Technology On Performance Of Surakarta City Government Financial Reporting. International Journal of Economics, Business and Accounting Research (IJEBAR), 3(01), 43-46.

Iskandar, D. (2018). Strategi Peningkatan Kinerja Perusahaan Melalui Pengelolaan Sumber Daya Manusia dan Kepuasan Kerja dan Dampaknya terhadap Produktivitas Karyawan. Jurnal Ilmiah Bisnis Ekonomi Asia, vol. 12, No. 1, pp. 23-31.

Mandang, Lumanauw, \& Walangitan. (2017). Pengaruh Tingkat Pendidikan dan Pelatihan terhadap Kinerja Karyawan pada PT. Bank Rakyat Indonesia (Persero), Tbk Cadang Manado. Jurnal Riset Ekonomi Manajemen Bisnis dan Akuntasi, vol. 5, No.3, pp. 4324- 
4335 .

Pamungkas, Hamid, \& Prasetyo. (2017). Pengaruh Pendidikan dan Pengalaman Kerja terhadap Kemampuan Kerja dan Kinerja Karyawan PT. INKA (Persero). Jurnal Administrasi Bisnis, vol. 43, No. 1.

stp.sragenkab.go.id, (2019, 02 Januari), UPTLK Technopark Ganesha Sukowati Dinas Tenaga Kerja Kabupaten Sragen, diakses pada 01 Oktober 2019, dari www.stp.sragenkab.go.id

Sukarjati, Minarsih, \& Warso. (2016). Pengaruh Kepemimpinan, Pengembangan Sumber Daya Manusia dan Kepuasan Kerja terhadap Kinerja Pegawai Kantor Dinas Pengelolaan Keuangan dan Aset Daerah Kota Semarang. Journal of Management, vol. 02, No. 02. 